\title{
Kerrie Davies
}

\section{The flâneur as a motif of timelessness in auto / biography}

\author{
Abstract \\ Prior to writing A Wife's Heart (Davies 2017), I did not see myself as a \\ flâneur. I walked in public spaces, but I often hurried rather than strolled. \\ When I did slow, I found myself having spontaneous conversations with \\ strangers. A flâneur seemed too leisurely an observer of the crowd; too \\ detached. An exegetical examination of my work, however, together with a \\ historical understanding of the flâneur, led to the realisation that flánerie was a \\ motif integral to my writing process, and to creating a narrative of timelessness \\ over a century of divorce and single parenting. My moments of flânerie, \\ punctuated with engagement among the crowd, also change the dynamics of \\ the flâneur to a dialogic and empathetic experience. A similar flânerie is \\ evident in the auto / biography Stasiland (Funder 2002), which explores the \\ pervasive presence of East German history after Germany's reunification. I \\ suggest that the fluid mindset of a flâneur suits the writer on a quest (Marr \\ 2016-2017), augmenting specific interview, archival and site research practices \\ with sensory awareness and a dialogic empathy in such auto / biographical \\ works. I further argue that the slash between the auto and biography is \\ dissolved via the flaneur becoming a motif of timelessness. \\ Keywords: flâneur, auto / biography, memoir, Henry Lawson, Anna Funder \\ Stasiland
}

\section{Introduction}

If a flâneur is a 'kaleidoscope gifted with consciousness' (Baudelaire 1964 [1863]: 9), I was not awake to its possibilities until reflecting upon my work, $A$ Wife's Heart (Davies 2017). I walked in public spaces, but I often hurried among the crowd rather than strolled. A flâneur seemed too leisurely an observer as articulated by Charles Baudelaire (1964 [1863]) and Walter Benjamin (1999 [1940]). He - for the flâneur was historically masculine - was also detached while I engaged with a montage of strangers in taxis, in swimming pools and in railway tunnels. I was too friendly, too open to dialogic encounters, too female-identifying to be a flâneur, distilled into a simplistic definition by the online Oxford Living Dictionaries as, 'a man who saunters around observing society' (2019). Gender aside, sauntering seems a perplexing description when I consider Edgar Allan Poe's flâneur in 'The Man of the Crowd', who shadows rather than saunters after the man who fascinates him (1840).

I didn't saunter after or shadow any faces in the street during the flânerie that occurred as I wrote $A$ Wife's Heart. The book centres on a biography of Henry and Bertha Lawson's marriage breakdown in 1903 and the conflict after, paired with a contemporary memoir of my life as a single parent to form a dual 
narrative that Sidonie Smith and Julia Watson describe as auto / biography or $\mathrm{a} / \mathrm{b}$ :

This term signals the interrelatedness of autobiographical narrative and biography. Although the slash marks their fluid boundary they are in several senses different, even opposed forms. The term also designates a mode of the autobiographical that inserts biography / ies within an autobiography, or the converse, a personal narrative within a biography. (Smith \& Watson 2010: 256)

Anna Funder's Stasiland combines a personal narrative of her life in Berlin with biographies of those who lived under the Stasi regime post-World War II (Funder 2002a), so I also see her work as one of auto / biography, and I will be exploring the genre, and its relationship to the flâneur, in more depth later in this paper.

To be clear, it is only unintended observations or encounters that I see as flânerie, not the arranged interviews or specific site visits that inform Funder's research and mine; the latter are essentially journalistic and historical in nature. I see the difference as intent. Flânerie appears uninvited and unexpected, and sparks some intriguing thought or connection that stays with you after that moment has passed. Examples from Stasiland that I do not see as flânerie include Funder arranging interviews with Miriam, her protagonist in Stasiland, or visiting the 'puzzle women' who reconstruct shredded Stasi documents (2002a: 263). My interview with the archivist of the National Art School, formerly Darlinghurst Gaol where Lawson was incarcerated for non-payment of child support (Davies 2017: 169) or visiting the Imperial War Museum, which was once Bethlem Royal Hospital where Bertha was a patient (60), carries similar expectations of new knowledge. In Woolloomooloo: A Biography, Louis Nowra distinguishes the flâneur from an 'objective reporter': 'In fact he glories in his attraction to the temporary, the ephemeral, the subjects not considered by the historian. For him, the past is a spectral but persistent presence' (Nowra 2017: 9). Nowra's view aligns with my interpretation of how the flâneur can create a motif of timelessness in auto / biography narratives, which I will return to later in this article.

Flânerie is an accumulation of the unexpected and uninvited. As I walked in Sydney's inner city I glimpsed ghost signs on buildings and met a homeless woman with happy face tattoos on her arms in a railway tunnel. Resting at the end of the pool during a swim, I listened to two women dissecting a text message from a man one briefly dated as they splashed with kickboards to the end of the lane. I stepped on a silver plaque embedded into a pavement memorialising Dame Mary Gilmore, listened to a taxi driver confide his love for his ex-wife, and noticed Henry Lawson lookalikes at a party at the National Art School. I watched an elderly man tenderly support his wife down the train carriage stairs. This flânerie filtered into my writing and wove around my biography of Bertha Lawson, and my memoir.

I see a similar flânerie in Funder's acclaimed Stasiland.At stations and on trains, walking through East Berlin, and in swimming pools too - which must be a peculiarly Australian aquatic flâneur - Funder's flânerie is evident and illuminates the pervasive presence of East German history and memory postreunification. I've come to appreciate, through studying Funder's flânerie and reflecting upon my own practice, that flânerie is also sensory (Boutin 2012), deepening my understanding beyond vision. Later in this reflection I will discuss this sensory reach in my own work as well as Funder's. 


\section{The flâneur}

Literary critic James Wood sees the origin of the flâneur as integral to innovative realism: 'Flaubert founds this new style of realism on his use of the eye - the authorial eye, the character's eye... Flaubert's Frédéric is a forerunner of what would later be called the flâneur' (Wood 2008: 39). Charles

Baudelaire in 'The Painter of Modern Life', draws on Edgar Allen Poe's 'The Man of the Crowd' (1840) when extolling the flaneur, 'Monsieur G' (the artist Constantin Guys). Baudelaire suggests, 'We might liken him to a mirror as vast as the crowd itself' (1964 [1863]: 9). Priscilla Parkhurst Ferguson notes that Baudelaire's flâneur had already developed from the 'triumphant Balzacian figure' to one who was more ambivalent and representative of urban displacement and exile (Parkhurst Ferguson 1994: 81). If Parkhurst Ferguson's view of the flâneuris to be accepted, then the flâneur represents self-exile and self-displacement in order to observe and be inspired.

The flâneur was later revived by Walter Benjamin (1999 [1940]), who positioned him as an artist, modernist historian and motif (Birkerts 1982). Robert Fulford sees Benjamin's flânerie as creating a new historical narrative, 'presenting a crucial period through a careful collection of facts, ideas, images, minutiae, and esoterica' (Fulford 2006). Conor McGarrigle highlights how the flâneur's preferred pace matched the turtle they walked on a leash, which 'could be seen in this context as a protest both against the increased pace of life and the rationalism of Taylorist clock time' (McGarrigle 2013: 1). McGarrigle is concerned with the çyberflâneur who cyber-strolls through the internet, and similarly the flâneur has been socio-technologically reconceptualised as the phoneur, who views the world through their phone (Luke 2005) - realised through the 180k plus Instagram posts tagged with \#flaneur (Instagram 2019).

In the tradition of Baudelaire and Benjamin, I still ground the flâneur in the physicality of walking, sans turtle. But I suggest that our 'hypermediated culture' (Soukup 2013: 228) has transformed the flâneur's pace to that of a distracted hare. Chris Jenks and Tiago Neves suggest such jumpy flânerie is a valuable research strategy of the contemporary urban ethnographer, who 'introduces a phenomenology of the urban built around the issues of the fragmentation of experience and commodification, opening the way for a micro-sociology of the urban daily life' (Jenks \& Neves 2009 [2000]: 1-2). Charles Soukup captures his fragmented flânerie at Starbucks, simultaneously listening to his iPod, watching a mounted, muted screen showing news, and noticing another customer playing on her phone while waiting for her friend, and others engrossed in their devices. Soukup sees the visit to Starbucks as representative of the postmodern flâneur's practices, 'repeated in public spaces like airports, franchise restaurants and shopping malls' (2013: 227).

I see my own experience of flânerie within this hypermediated culture. I would often be answering texts or emails on my phone while walking or travelling and observing at random. Instead of writing the details of my observations in a notebook, I typed notes on my phone and iClouded them to my laptop. They weren't filed under 'flâneur' nor, as I flagged in the introduction, was I identifying as such at that time. Instead, I instinctively recognised these fleeting moments as important to record separate to my historical research or journalistic inquiry.

Perhaps it was because the flâneur was historically constructed as male consider Nowra describing the flâneur as 'him' as recently as 2017 - that I didn't connect to my inner flâneur. Bart Van Leeuwen adds class and race to 
the figure of the flâneur, noting that, 'The flâneur is typically an aristocratic white male with lots of leisure time' (Van Leeuwen 2017: 7). But I've since discovered that feminist scholarship has addressed the concept (Olofsson 2008; Nesci 2012; Elkin 2016). In her thoughtful discussion of the flâneur, Catherine Nesci observes that her feminist inquiry 'dislocated the flâneur's panoramic embrace of sites / sights of authority’ (2012: 136).

Stasiland references Alice's Adventures in Wonderland (Carroll 1865), the Victorian flâneuse of fairytales (Swamidoss 2014) that subsequently frames Funder as an innocent female outsider in a fascinating and potentially dangerous world. Priscilla Parkhurst Ferguson reminds us that in Balzac's view, women were to be observed (Parkhurst Ferguson 2014 [1994]: 26), enduringly highlighted by the interactive survey app 'Free to Be' (Plan International 2018) that encourages women to geolocate their experiences so as to cumulatively represent a flânerie of fear and harassment. Funder writes of walking through a park that is 'dark on dark' (2002a: 47) but does not dwell on her feminine self within the public space. So, while the revised term flâneuse (Elkin 2017) is revisionist and relevant, neither myself nor Funder construct a specifically female flâneur; perhaps, unlike Nowra, Funder does not identify as a flâneur in Stasiland or in her discussions around the book; and I am only exegetically considering its influence.

Bijan Stephen suggests that the flâneur has been used ever since Benjamin as 'a vehicle for the examination of the conditions of modernity - urban life, alienation, class tensions and the like' (Stephen 2013). Stasiland and A Wife's Heart both have sociopolitical themes at their cores - in the former, the pervasion of political history, and in the latter, the enduring conflict of divorce - and thus examine our post-modernity. As Stephen suggests, the flâneur's spontaneity of observation is a means to examine lives in the current age, but also a means to examine the pervasiveness of history, as Funder's encounters and experiences in former East Berlin reveal.

Benjamin's imagery of the flâneur who 'still stands on the threshold' (1999 [1940]: 10) has synergy with the immersive observer who recognises the power of telling details (Wolfe 1973). Writers, offers James Wood, 'navigate via the stars of detail' to create characterisation and symbolism (2008: 52). Wood sees the grief symbolised by Leonard Woolf's smudged page of an otherwise immaculate journal, written on the day Virginia Woolf drowned; the distrust sparked by Nixon's five-o-clock shadow in the TV camera's glare, and the randomness of death in mountaineer Joe Simpson's irritation that a Boney M song he disliked earwormed into his mind as he dangled from a rope with a broken leg (48-52). I see Funder navigating via such stars as she immerses herself in Berlin, and reflecting upon her practice and my own, I now realise that perhaps my unknown guiding compass was the flâneur in writing $A$ Wife's Heart.

\section{The flâneur and auto / biography}

Stasiland and A Wife's Heart can be described as auto / biography as both books have a personal narrative and a biographic subject(s). The use of the self in these works of auto / biography is divisive, which for me makes the form that much more interesting. Biographer David Marr evidently loathes the use of first-person perspective in forms of biography that he describes as 'quests' and likens it to a playwright clambering onto the stage (2016-2017: 66), intrusive and distracting to the audience. It does not always work, and the value of the autobiographical subject in these works is in the eye of the reader. 
Smith and Watson are more open than Marr to the auto / biography's possibilities. Returning to their definition, I note that 'biography / ies' implies collective biography, which they separately categorise as prosopography: 'A practice of making a collective study of the characteristics shared by a group ... in order to discover relationships and patterns among their lives at a particular historical moment' (Smith \& Watson 2010: 278). Funder focusses on Miriam, who was a teenager at the time of the Stasi, but interviews former Stasi agents, and other survivors of the Stasi regime.

In their definition of auto / biography, Smith and Watson refer to personal narrative as the foundational 'auto' that is as varied as the sixty genres of life writing they have described (2010: 253), including a detailed snapshot of the scholarship of memoir which I now extract from: 'Currently the term refers generally to life writing that takes a segment of life, not its entirety and focusing on interconnected experiences' (275). With this thought in mind, I suggest that in A Wife's Heart, the 'auto' is my memoir of single parenting and divorce, and the biography is of course about the Lawsons.

Funder's 'auto' is less straightforward. Recalling events that occurred in the past while a single parent is clearly memoir; a decision to move to Berlin and research life under Stasi surveillance as Funder did (2002a: 9) is to my mind, something entirely different. To go on a small tangent, Funder's methodology fits with the technique of immersion, favoured by longform (book length) journalists who spend weeks, months or ideally at least a year observing those they are writing about (Sims 1984). To this end, Funder clearly indicates her intention to research the Stasi, and once established in Berlin, 'set about looking for some of the stories from this land gone wrong' (2002a: 9). I suggest that Funder's 'auto' is that of interviewer, posited by Smith and Watson within the broader life genre of the 'as told to' collaborative life writing (2010: 265). This is distinct from my reflective memoir 'auto' in $A$ Wife's Heart.

Funder's 'auto' bears witness to a series of others' stories, primarily Miriam's story, supported by interviews with former Stasi police and survivors to form the prosopography on the other side of the auto / biography slash. Much of the text reads like an extended transcript between Funder and her interviewees, or accounts of their experiences interwoven with her own reactions to the trauma she hears. According to Leah Gerber, "Funder presents these "real stories" mediating them as explained to Anna - as a means of validating her creative non-fiction text' (Gerber 2016: 221). The second chapter, 'Miriam' (2002a: 1018 ), begins with a tense discussion between Funder and her editor at an overseas television service based in Berlin. The editor resists Funder's requests to do more stories about the former East German experience. But Funder is the outsider, an Australian with a looking glass that reflects a history still vivid for those who lived it, albeit in a way which has been critiqued as myopic on the GDR experience (Gerber 2016: 224). Funder lets her glass linger on Miriam, who compellingly and at length over the following chapters describes how, 'I became an enemy of the state at sixteen. At six-teen' (2002a: 15, original emphasis). Funder, in interviewer 'auto' mode, asks questions and reflects on her reactions, such as when Miriam mentions a wedding photo that she cut herself out of: 'I want to ask but I sit tight' (33).

Whether auto (memoir) / biography /ies or auto (interviewer)/ prosopography, there is a 'fluid boundary' (Smith \& Watson 2010: 256) between the auto of the narrator, and the story of another / others that is being told. Julia Watson points out that, 'There is a relational aspect to nearly all life narratives' (Watson 2016: 16) which opens to this auto / biographic relationship. In the case of $A$ Wife's Heart, the separate elements of contemporary memoir and historical biography were challenging. After a few false starts, I found the relational narrative flow 
by weaving the two stories together throughout the book. Rather than presenting them as separate parts, I reflected via memoir upon contemporary parallels I saw in the biographical narrative. The latter is interspersed with archival letters and legal documents, such as the controversial affidavit in which Bertha Lawson alleged drunkenness and cruelty (2017: np). Stasiland's 'auto' of interviewer and the biographies of those Funder meets have a more immediate connection and so are more overtly relational, but still distinct. This tension is articulated by Leigh Gilmore as a demand:

The demands of the autobiography (to tell my story) and the demand of biography (to tell your story) coincide... The instability within the auto / biographical act produces constraints that the auto / biographer manages through form to some extent; yet the writing subject is still caught up in, indeed emerges through, his or her implication in a family, a culture, even in a self. (Gilmore 2001: 72)

Such an auto / biographic demand is evident in A Wife's Heart.The 'writing subject' speaks to women's experiences of single parenting thatI am implicated in and exposed by. For Funder the demands are geographic and cultural, as an Australian in Berlin immersed in a past that is not yet reconciled with the reality of reunification. Stasi men feel disempowered and impoverished; citizens feel liberated but unable to feel fully free after living under surveillance. Funder's reactions to the stories she hears expose her subjective self, which expands her observations to include the unexpected and uninvited flânerie.

\section{The flâneur as a motif of timelessness in auto / biography}

Where then to place the flâneur in auto / biography? What is its role in the quest? At first it seems very much on the side of the 'auto'. But as Benjamin recognises, the flâneur is a more symbolic motif. As Sven Birkerts explains, 'Benjamin's flâneur is a motif, a concept in many ways different from the historical flesh and blood stroller who wandered the boulevards and passages of 19th century Paris' (1982: 165). Wood also recognises this temporal motif, arguing that, '[Flaubertian realism] is lifelike because detail really does hit us, especially in big cities, in a tattoo of randomness. And we do exist in different time signatures' (2008: 46). The thematic significance of the motif also appears in the idolisation of the flâneur in psychogeography, which as Siobhan Lyons explains is 'crucial in understanding the complication between the histories and myths of urban landscapes' (Lyons 2017). Thus, the flâneur as motif gathers meaning 'in the small individual moment the crystal of the total event' (Benjamin 1999 [1940] qtd in Fulford 2006).

Thinking exegetically about the flâneur's influence in my work, I've come to a wider realisation that the flâneur's 'tattoo of randomness' creates a motif of timelessness, connecting place, time and experiences that together form 'the confetti of history' (Fulford 2006), albeit often at a fragmented and faster pace that speaks to our current urbanity. I suggest the flâneur's motif of timelessness inhabits the space in between the auto and biography and is a possible solution to the 'irresolvable narrative dilemma' created by the auto / biographic demand (Gilmore 2001: 72). In both works, the flânerie dissolves the present into the past, thus dissolving the slash dividing them.

Using the flâneur as a motif of timelessness, Funder evocatively moves between the present of reunification and the past embodied by the memories of 
the survivors whom she is interviewing. The result is a reminder of the living nature of history. Funder is narrating - as there is clearly no other ' $\mathrm{I}$ ' in the work but her own voice - but her flânerie is distinct from her own auto collaborative narrative and is thus instead a motif of timelessness. On the way to meet Stasi survivor Frau Paul, Funder buys a bunch of flowers from a flower seller, who 'has a face stretched like a Mummy and teeth that don't fit in his mouth' and who offers her black-market cigarettes with her flowers (2002a: 204). Upon meeting Frau Paul, Funder's flânerie is on the threshold, literally and metaphorically. As Funder observes, 'her clothes and hair are neat and she has the tapered plump fingers of a mournful Magdalene' (205). The flânerie fades out as Funder steps into the room as interviewer and Frau Paul's voice fades in and occupies the pages to the end of the chapter (205-212).

Funder later ties up loose biographic ends, visiting Miriam on a spontaneous, unannounced visit. But these final chapters are much more meditative, as she absorbs both what she sees, and what she now knows. The flâneur emerges from the textual shadows and is walking Funder to the end: 'In this soft Spring I have taken to walking everywhere' (253).

I see a similar movement in my writing as the timelessness motif manifests in a flânerie of observations that I narrate, but it is distinct from my auto narration of memoir in the auto / biography. Walking through the Sydney streets, over a century after Henry and Bertha resided there, I write:

Ghost signs remain on the streets. A leather-goods shop sign is bleached into brick on a Castlereagh St wall. Further along at number 221, is the site of McNamara's bohemian Bookshop... Where once communist posters hung in the demolished bookshop, the Bank of Sydney now displays its interest rates in the windows, which are painted a plain, steel grey. (Davies 2017: 10)

And in the Botanical Gardens, where Bertha and Henry strolled on the day they met outside the bookshop, I reflect:

More than a century later, I walk through the Botanic Garden to the Chair and wonder if the bats shat on Henry and Bertha too. There has been a campaign to move the bats on as they are destroying the old trees, but they cling to the branches above.

Returning to psychogeography, the ubiquity of Henry Lawson's mythology in Sydney, and the erasure of his wife Bertha, appear through the flâneur as a motif of timelessness:

Henry is part of the city. He is a sudden appearance during a stroll. Walking from the city through the gardens, you can exit though the Henry Lawson Gate to get to Mrs Macquarie's Chair and the harbourside pool. A postcard featuring a drawing of Henry Lawson's headstone on the clifftop at Waverley Cemetery is on a stand at Bondi. On a bushwalk around Berry's Bay a verse from his poem, 'Kerosene Bay' is inscribed into the concrete... He's been mythologised, anthologised and analysed.

Bertha has been forgotten. Filed away in boxes of letters, birthday cards and notes. (9-10)

In Stasiland, the flânerie as timelessness motif captures the psychogeography of Berlin's complex political history that lingers after reunification, and from 
the micro-observations she draws macro-realisations in the spirit of Benjamin's modernist historian. On a train in Germany's east, Funder reflects, 'It is a country that no longer exists, but here I am on a train hurtling through it - its tumbledown houses and bewildered people' (2002a: 4). On the same journey, Funder observes another passenger smoking 'west' cigarettes, 'which seem to be the most popular brand here since the fall of the Wall' (4).

\section{The flâneur and sensory space}

The flâneur's relationship to temporality and motif can be more fully realised within the sensory turn of the humanities. Aimee Boutin highlights how vision has been privileged over other sensorial flânerie, such as the aural experience, resulting in 'privileges of the eye over the ear in the modern metropolis' (Boutin 2012: 149). Drawing on Balzac, Boutin instead reflects on the city as a 'musical score' and how 'aural flânerie describes walking in the city as a multisensory embodied experience rather than a disengaged spectatorship' (150). She continues, 'Getting in touch with the flâneur's sensory experience can move us beyond the myth of the detached disembodiment of the flâneur' (152).

I can see Boutin's multisensory flâneur in my own work, and in Funder's. While researching $A$ Wife's Heart,sensory spatial experiences arose such as the man yelling at the rain on a London street near where Henry and Bertha lived after her release from Bethlem Royal Hospital (Davies 2017: 63). In an address to the Sydney Institute, Funder explained she saw her work as being about a place that no longer exists, and human courage (Funder 2002b). Funder's flânerie of this non-existent place is first visually seen through a monochromatic 'confetti of history' (Fulford 2006). Funder privileges vision: she sees the colours of the former GDR as defiantly drab, a dull reminder despite the wish for this history to be forgotten. Funder's apartment building in former East Berlin is 'grey sprayed on concrete' (2002a: 47) and she writes, 'I inhabit the grey end of the spectrum; grey buildings, grey earth, grey birds, grey trees' (3). But other senses appear. In a train station restroom, she recoils at the 'sick smell of antiseptic' (2) and a colleague who gives her a lift home 'smells like smoke and fake pineapple, like a seedy Hawaiian' (121).

In the final chapters, it is in the full sensory flânerie where a future emerges. Returning to Leipzig to see Miriam, Funder notices that ' $[\mathrm{t}]$ he air is quiet apart from birdsong and the soughing of trams' (272). She feels warmth. Buildings are now painted yellow-pink and scaffolding removed. These sensory experiences surround the research significance of site visits, leading to a flânerie that deepens observations of time and place, and evokes the spontaneity of a flâneur's observation in the street, park or swimming pool.

\section{A dialogic, empathetic flâneur}

The development of the flâneur as detached is curious given how Poe writes of the man he follows: 'I gazed at him steadfastly in the face' (Poe 1980 [1840]: 104), implying he sought direct engagement with the man who so fascinated him. Van Leeuwen argues the flâneur is passive:

To conceive of flânerie as a step towards moral cosmopolitanism requires a change in the practice of flânerie, namely from detached, uncommitted observation of 'the other' 
to more meaningful modes of interaction. (Van Leeuwen 2017:

2)

Baudelaire distinguishes the flâneur from the dandy on the basis that Monsieur G, his model flâneur, is a 'passionate spectator' who feels the crowd and delights in its sights (1964 [1863]: 9), which implies the flâneur can be sensory, or even empathetic, although this empathy is internalised. I instead suggest that a dialogic flâneur communicates the empathy that is felt, deepening his or her engagement with the crowd and thus producing a 'more meaningful mode of interaction' (Van Leeuwen 2017: 2).

Empathy is affective, cognitive, and emotionally regulated, allowing a person to share or understand the emotions of others, or restrain their own feelings in order to control a situation (Molenberghs 2017). In Funder's conversations with strangers, there is a cognitive empathy, a respect for other voices and experiences of the street that encourages the motif of timelessness to emerge, such as when Funder encounters a drunk man in a park:

'I don't want to be German anymore,' he sobs. 'I don't want to be German anymore!' His face is tracked with silver tears. 'Why not?' I hold out a hand to steady him. (Funder2002a: 253)

As previously discussed, Funder's dialogic and empathetic flânerie is distinct from her dialogue with interview subjects or during site specific research. Stasiland begins with dialogic flânerie that is not an arranged interview. Funder is feeling ill, and at the Alexanderplatz Station, East Berlin, goes to the restroom. There, outside, she encounters 'the toilet madam' who is 'leaning on a glass-paned counter guarding her stash of condoms and tissues and tampons. This is clearly a woman who is unafraid of the detritus of life' (2002a: 2). The woman boasts to Funder that she's been at the station for twenty-one years, and one of her station admirers was a Prince who invited her to the West, ' $[\mathrm{b}]$ ut of course I couldn't go' (3). Funder suspects she is exaggerating, but in her wish to understand more asks:

'Have you travelled yourself since the Wall came down?'

She throws her head back. I see she is wearing purple eyeliner which, at that angle, phosphoresces.

'Not yet. But I'd like to. Bali, something like that. Or China. Yes, China... You know what I'd really like to do? I'd like to have me a look at that Wall of theirs'. (3)

Their exchange shows the potentiality of the dialogic flâneur to illuminate both empathy and timeless temporality. The toilet madam is now free to travel, but as Funder identifies later in the book as a complaint common to former East Germans, there is little point to that freedom if she cannot afford it (251). Funder sees irony in the madam's wish to see the Great Wall of China, for, despite reunification, she remains bound economically and psychologically to life behind a wall.

I now see a similar empathy in my writing process in $A$ Wife 's Heart. In a taxi, I have the following exchange with the driver who confesses his love for his exwife:

'I see things she likes and I buy to give to her... I ask our son to ask her if she wants to come back. But he said, no she doesn't and you are better living apart - you fight.'

'So, you love her, but you can't live together?' I venture.

'Yes. Maybe if I find another woman, I can forget about her.' 
He brakes the cab, still talking about his ex. At the kerb I pay

the fare and he drives back into his life. (Davies 2017: 194)

It's a burst of dialogic flânerie, the motif at work, showing the timelessness of relationship conflict, marriage and divorce more than a century after Henry and Bertha Lawson separated acrimoniously.

\section{Conclusion}

Through flânerie that spans sensory spatial observations and dialogic encounters, in modes of mobility from walking to swimming to commuting, both Stasiland and A Wife's Heart are auto / biographic narratives with sociopolitical timelessness at their core.

The flâneur as a motif of timelessness dissolves the separation between my 'auto' memoir and the Bertha Lawson 'biography' to become an integral part of the quest. In A Wife's Heart, my flâneur becomes a motif of the timelessness of relationship conflict and divorce; backgrounded by the pervading mythology of Henry Lawson. In Stasiland, Funder's flânerie is a similar motif of timelessness, constantly illuminating the legacy of the former GDR and its culture of surveillance in the present reunification. That Funder researched Stasiland in the late nineties, less than a decade after reunification in 1989, makes the flâneur as timelessness motif narrower but its enduring power is emphasised by Reiner Klingholz, director of the Berlin Institute for Population and Development, who argues, 'it will take at least another generation for the two parts [East and West Germany] [to] have truly grown together', noting that wealth indicators remained mostly in the West, with an East German having a $25 \%$ higher chance of slipping into poverty (Connolly 2015).

Funder has not explicitly discussed her flânerie, only, as mentioned, noting her obsession with a place that did not exist (2002b). But a close reading of her work reveals a flâneur who is dialogic and sensory, which takes flânerie into the arena of dialogic empathy as well as temporality. As a dialogic, empathetic, sensory flâneur, Funder is as comfortable observing on commuter trains as in cafes, in pools as much as in parks, and is empathetic in hearing what the crowd has to say as she moves among the throng. Seeing such a flânerie at work in Funder's writing process, and reflecting upon its role in my own, has awakened my consciousness to its presence and possibilities.

\section{Works cited}

Baudelaire, C 1964 [1863] 'The Painter of Modern Life', in J Mayne (ed \& trans) The Painter of Modern Life and other essays, Phaidon Press, London: 1-41 return to text

Benjamin, W 1999 [1940] The Arcades Project, H Eiland \& K McLaughlin (trans), Harvard University Press, Cambridge MA return to text

Birkerts, S 1982 'Walter Benjamin, Flâneur: A Flânerie', The Iowa Review 13, 3: 164-179

return to text

Boutin, A 2012 'Aural Flânerie', Dix-Neuf 16, 2: 149-161 return to text

Carroll, L 1865 Alice's Adventures in Wonderland, MacMillan, London return to text

Connolly, K 2015 'German reunification 25 years on: how different are east and west really', The Guardian (2 October): https://www.theguardian.com/world/2015/oct/02/german- 
reunification-25-years-on-how-different-are-east-and-west-really (accessed 29 May 2018) return to text

Davies, K 2017 A Wife's Heart: The Untold Story of Henry and Bertha Lawson, University of Queensland Press, Brisbane return to text

Elkin, L 2016 Flâneuse, Chatto \& Windus, London return to text

Fulford, R 2006 'Walter Benjamin, The Flâneur, and the Confetti of History', Queens Quarterly 113: http://www.robertfulford.com/benjamin-2006.html (accessed 29 May 2018) return to text

Funder, A 2002a Stasiland, Text Publishing, Melbourne return to text

Funder, A 2002b 'Stasiland: Writing a World Gone Wrong', The Sydney Papers 14, 2: 60-71 return to text

Gerber, L 2016 'Behind the Wall, through Australian eyes: Anna Funder's Stasiland', in N Moore \& C Spittel (eds) Australian Literature in the German Democratic Republic: Reading Through the Iron Curtain, Anthem Press, London: 221-237 return to text

Gilmore, L 2001 The Limits of Autobiography: Trauma and Testimony, Cornell University Press, Ithaca return to text

Instagram 2019 ‘\#flaneur’: https://www.instagram.com/explore/tags/flaneur/?hl=en (accessed 17 April 2019) return to text

Jenks, C \& T Neves 2009 [2000] 'A walk on the wild side: Urban ethnography meets the Flâneur', Cultural Values 4, 1: 1-17 return to text

Luke, R 2005 'The Phoneur: Mobile Commerce and the Digital Pedagogies of the Wireless Web' in P Trifonas (ed) Communities of Difference: Culture, Language, Technology, Palgrave MacMillan, New York: 185-204 return to text

Lyons, S 2017 'Psychogeography: A way to delve into the soul of a city', The Conversation: https://theconversation.com/psychogeography-a-way-to-delve-into-the-soul-of-a-city-78032 (accessed 2 March 2019) return to text

Marr, D 2016-2017 'The Art of Biography', The Monthly December-January: 64-68, https://www.themonthly.com.au/issue/2016/december/1480514400/david-marr/art-biography (accessed 2 March 2019) return to text

Marr, D 2018 [1991] Patrick White, A Life, Penguin, Sydney

McGarrigle, C 2013 'Forget the Flâneur', in K Cleland, L Fisher \& R Harley (eds) Proceedings of the 19th International Symposium of Electronic Art, ISEA2013, Sydney:

http://ses.library.usyd.edu.au/handle/2123/9475 (accessed 3 March 2019) return to text

Molenberghs, P 2017 'Understanding others' feelings: what is empathy and why do we need it?', The Conversation:

https://theconversation.com/understanding-others-feelings-what-is-empathy-and-why-do-weneed-it-68494 (accessed 29 May 2018) return to text

Nesci, C 2012 'Sensual Re-Readings: Gender, Sensibility, and the Classes of Flânerie', DixNeuf 16, 2: 133-148 return to text

Nowra, L 2017 Woolloomooloo, NewSouth Publishing, Sydney return to text

Olofsson, J 2008 'Negotiating figurations for feminist methodologies - a manifesto for the fl@neur', Graduate Journal of Social Science 5, 1:71-93 return to text

Oxford Living Dictionaries, 'flâneur', Oxford Living Dictionaries: https://en.oxforddictionaries.com/definition/flâneur (accessed 1 March 2019) return to text

Parkhurst Ferguson, P 1994 Paris as Revolution: Writing the Nineteenth Century City, University of California Press, Berkeley return to text 
Parkhurst Ferguson, P 2014 [1994] 'The flâneur on and off the streets of Paris 1', in K Tester (ed) The Flâneur (RLE Social Theory), Routledge, London: 22-43 return to text

Plan International 2018, 'Girls Speak Out about Street Harassment', Plan International: https://www.plan.org.au/freetobe return to text

Poe, EA 1980 [1840] 'The Man of the Crowd', in J Symons (ed) Edgar Allan Poe Selected Tales, Oxford University Press, Oxford: 97-104 return to text

Sims, N 1984 'Introduction', in N Sims (ed) The Literary Journalists, Ballantine, New York: 127 return to text

Smith, S \& J Watson 2010 Reading Autobiography: A Guide for Interpreting Life Narratives, University of Minnesota Press, Minneapolis return to text

Soukup, C 2013 'The Postmodern Ethnographic Flâneur and the Study of Hyper-Mediated Everyday Life', Journal of Contemporary Ethnography 42, 2: 226-254 return to text

Stephen, B 2013 'In Praise of the Flâneur', Paris Review:

https://www.theparisreview.org/blog/2013/10/17/in-praise-of-the-flaneur/ (accessed 18 March 2019) return to text

Swamidoss, H 2014 'From Chimney Sweeps to House-Elves: Housework, Subject Formation, Agency, and British Children's Fantasy Literature, 1863-2007', in E Patton \& A Choi (eds) Home Sweat Home: Perspectives on Housework and Modern Relationships, Rowman \& Littlefield, Lanham MD: 49-68 return to text

Van Leeuwen, B 2017 'If we are flâneurs, can we be cosmopolitans?', Urban Studies 56, 2: 301-316 return to text

Watson, J 2016 'Is Relationality a Genre?', European Journal of Life Writing 5: R16-R25 return to text

Wolfe, T 1973 'Seizing the Power', in T Wolfe \& E Johnson (eds) The New Journalism, Harper Row, New York: 37-51 return to text

Wood, J 2008 How Fiction Works, Jonathan Cape, London return to text

Dr Kerrie Davies is a lecturer in media at the School of the Arts and Media, UNSW, Sydney. She is the author of A Wife's Heart (2017), an auto / biography of Bertha Lawson, divorce and single parenting that attracted national media attention. Kerrie has appeared at the Sydney Writers' Festival, Brisbane Writer's Festival and Canberra's National Folk Festival. Her research interests include literary journalism, auto / biography and other forms of life writing.

\section{TEXT}

Vol 23 No 1 April 2019

http://www.textjournal.com.au

General Editor: Nigel Krauth. Editors: Julienne van Loon \& Ross

Watkins

text@textjournal.com.au 